\title{
Technical Guidance of Science Teachers in The Preparation of Scientific Based Teacher Books, to Improve Teacher Professionalism in West Pasaman Regency
}

\author{
Ratnawulan ${ }^{1}$ and Ahmad Fauzi ${ }^{1}$ \\ ${ }^{1}$ Jurusan Fisika, Universitas Negeri Padang, Jl. Prof. Dr. Hamka Air Tawar Padang, 25131, Indonesia \\ *ratnawulan@fmipa.unp.ac.id
}

Diterima 5 Desember 2019, Disetujui 21 Maret 2020, Dipublikasikan 31 Maret 2020

\begin{abstract}
There are problems in implementing integrated science learning in SMP / MTs in West Pasaman Regency. Most teachers do not have a handbook according to the nature of integrated science. Existing teacher books, the fields of biology, chemistry and physics are still not integrated into a single unit. The next problem, the low motivation and creativity of teachers in finding sources of information and integrating fields of study for learning. The solution offered is to increase the professionalism of science teachers is through technical guidance for making science-based Integrated science teacher books. Integrated science learning is designed with integrative thematic learning that is learning that integrates a learning concept with another subject. This Bimtek succeeded in increasing the competence of science teachers in MGMP Pasaman Barat in developing Integrated Science teacher books with themes in accordance with local wisdom with the Scientific Approach.
\end{abstract}

Keywords — Integrated Science, Teacher's Books, Technical Guidance, Professionalism

\section{Pendahuluan}

Konsep pembelajaran IPA berdasarkan Permendiknas No. 22 tahun 2006 dikembangkan sebagai mata pelajaran integrative science atau IPATerpadu bukan sebagai pendidikan disiplin ilmu. Pada kurikulum 2013 konsep keterpaduan ini ditunjukkan dalam Kompetensi Inti ( KI) dan Kompetensi Dasar ( KD) pembelajaran IPA yakni di dalam satu KD sudah memadukan konsepkonsep IPA dari bidang ilmu biologi, fisika, dan ilmu pengetahuan bumi dan antariksa (IPBA). Melalui pembelajaran IPA terpadu, peserta didik dapat memahami fenomena alam sekitar secara tuntas. Dengan demikian, peserta didik terlatih untuk dapat menemukan sendiri berbagai konsep yang dipelajari secara menyeluruh, tuntas, bermakna, autentik dan aktif [1].

Pelaksanaan pembelajaran IPA juga harus memberi penekanan pada pembelajaran saling temas (sains, lingkungan, teknologi, dan masyarakat). IPA sebagai ilmu tersusun atas empat komponen yaitu sebagai perangkat keilmuwan, telaah keilmuwan, perangkat pengamatan, dan perangkat analisis [2].

Di dalam pembelajaran IPA terpadu, permasalahan IPA hendaknya ditinjau dari dua atau lebih bidang kajian atau ilmu. Oleh karena itu, pelaksanaan pembelajaran IPA terpadu melibatkan lebih dari satu guru dalam setiap pembelajarannya (team teaching)[3,4] Dalam team teaching, guru-guru yang terlibat harus jelas tugas masing-masing seperti menyiapkan bahan ajar (silabus, RPP, media, sumber belajar, dan instrumen penilaian) dan melaksanakan kegiatan pembelajaran.

Disamping itu, dalam melaksanakan pembelajaran IPA terpadu, siswa hendaknya diberikan buku siswa yang berisi keterpaduan antara bidang ilmu biologi, kimia dan fisika. 
Demikian juga guru mempunyai buku penuntun pelaksanaan pembelajaran IPA Terpadu,

Akan tetapi kenyataan di lapangan, berdasarkan observasi dan wawancara yang dilakukan pada guru-guru IPA di kabupaten Pasaman Barat menunjukkan bahwa karena ketersediaan dan kemampuan guru yang ada di sekolah, maka banyak juga sekolah yang melaksanakan pembelajaran IPA terpadu dengan hanya satu orang guru. Disamping itu, walaupun buku siswa yang dikeluarkan depdiknas sudah disusun secara terpadu, namun buku guru masih terpisah-pisah bidang ilmu biologi, kimia dan fisika.

Pada dasarnya pembelajaran IPA terpadu bukanlah hal yang baru, karena sebagian dari guru-guru IPA telah menerapkan pembelajaran tersebut walau tidak menyadarinya, misalnya mengaitkan satu konsep dalam biologi dengan konsep lain yang relevan dalam fisika atau kimia dan sebaliknya. Akan tetapi, secara umum guru IPA belum memahami atau melaksanakan pembelajaran tersebut secara benar dan sistematis. Apalagi sebagian besar guru IPA di kabupaten Pasaman Barat memiliki latar belakang keilmuan yang spesifik, misalnya pendidikan fisika, kimia, atau biologi yang menyebabkan guru kesulitan dalam mengaitkan dengan benar antar bidang kajian IPA, belum lagi dengan model buku guru yang tidak sama dengan buku guru pada umumnya karena harus mengaitkan antar kompetensi dasar yang satu dengan yang lain sehingga menjadi suatu kajian pembelajaran yang saling terkait.

Hal ini membuat kebanyakan guru mengajarkan IPA sesuai dengan apa yang menjadi latar belakang keilmuwan spesik dari guru tersebut. Padahal jika guru mengetahui beberapa tipe pembelajaran yang dianjurkan dalam membelajarkan IPA Terpadu (Connected,integrated dan webbed) maka pembelajaran IPA Terpadu akan lebih mudah dalam pelaksanaannya.

Permasalahan yang terjadi pada pelaksanaan pembelajaran IPA Terpadu di SMP/MTSn di Kabupaten Pasaman Barat dapat dirinci sebagai berikut ini. pertama, guru (khususnya guru senior) sudah terlanjur terbiasa mengajarkan IPA secara parsial sesuai latar belakang keilmuannya, sehingga cenderung kesulitan ketika harus mengaitkan atau melakukan penggabungan berbagai bidang kajian IPA. Kedua, rendahnya motivasi dan kreativitas guru dalam menyusun mencari sumber-sumber informasi dan memadukan bidang-bidang kajian untuk pembelajaran. Ketiga, belum adanya upaya sistematik dari pihak yang berwenang untuk mengembangkan kemampuan guru di lapangan dalam melaksanakan pembelajaran IPA terpadu. dan Keempat, minimnya buku pegangan guru yang dapat digunakan sebagai acuan oleh guru IPA dalam merencanakan dan mengembangkan pembelajaran IPA terpadu.

Kondisi ini membuat pembelajaran IPA menjadi kurang diminati peserta didik, peserta didik tidak bisa terlibat penuh dalam pembelajaran dan materi IPA menjadi semakin sulit untuk di pahami peserta didik, akibatnya peserta didik sulit untuk mengembangkan kreaktifitas berpikirnya dan membuat sulit mencapai ketuntasan belajar yang telah di tetapkan oleh sekolah. Berangkat dari permasalahan diatas, maka solusi yang ditawarkan adalah Bimbingan teknis pembuatan buku guru IPA Terpadu berbasis saintifik. Bimbingan teknis ini diharapkan mampu meningkatkan profesionalitas dan pedagogik guru dalam mengampu matapelajatan IPA di SMP.

\section{Solusi/Teknologi}

Metode yang digunakan dalam kegiatan ini yaitu diskusi dan informasi, demonstrasi, diskusi dan latihan keterampilan, serta evaluasi.

1. Diskusi dan informasi digunakan pada kegiatan pendalaman materi IPA terpadu. Diskusi dan informasi yang diberikan mencakup tentang pentingnya keterpaduan dalam pembelajaran IPA di SMP, beberapa tipe pembelajaran yang dianjurkan dalam membelajarkan IPA Terpadu (Connected,integrated dan webbed) [5,6]. Cara merancang pembelajaran tematik integratif yaitu pembelajaran yang mengaitkan/mengintegrasikan suatu konsep pembelajaran dengan suatu fenomena/mata pelajaran lain, Contoh pelaksanaan pembelajaran IPA terpadu yang dirancang dengan pembelajaran tematik integratif, peranan bahan ajar tematik dengan 
pendekatan saintifik dalam pembelajaran IPA terpadu.

2. Demonstrasi, diskusi dan latihan keterampilan digunakan pada pelatihan pengembangan bahan ajar IPA terpadu tematik dengan pendekatan saintifik. Pada pendekatan pembelajaran terpadu mata pelajaran IPA, bahan ajar disusun dari berbagai cabang ilmu dalam rumpun ilmu sains. Pengembangan pembelajaran terpadu dapat mengambil suatu topik dari suatu cabang ilmu tertentu, kemudian dilengkapi, dibahas, diperluas, dan diperdalam dengan cabang-cabang ilmu yang lain. Tema dapat dikembangkan dari isu, peristiwa, dan permasalahan yang berkembang yang dekat dalam kehidupan sehari-hari peserta didik.

Fenomena yang terkait dengan tingkah laku peserta didik sendiri, sebagai contoh perilaku/perbuatan peserta didik yang memakai pakaian ketat, memakai pakaian hitam, memakai jaket pada saat terik matahari, dan perbuatan peserta didik yang suka berada di luar rumah sampai larut malam. Perilaku/perbuatan peserta didik ini tanpa sepengetahuan mereka telah menganggu/merusak kesehatan. Memakai pakaian ketat akan menghambat pelepasan panas dari tubuh ke lingkungan, akibatnya tubuh akan semakin panas dan suhu tubuh menjadi tidak seimbang, ketidakseimbangan suhu tubuh akan menimbulkan berbagai dampak salah-satunya ketidaknyamanan dan bahkan bisa mengakibatkan demam/sakit, begitu pula halnya dengan memakai pakaian serba hitam, memakai jaket pada saat terik matahari dan juga berada di luar rumah sampai larut malam, hal ini akan menganggu proses keseimbangan suhu tubuh. Dari fenomena di atas, perlu suatu upaya untuk menanamkan pemahaman tentang pentingnya menjaga keseimbangan suhu tubuh demi menjaga kesehatan. dimana pengetahuan ini dikaji pada fenomena thermoregulasi pada manusia. Thermoregulasi adalah suatu fenomena yang berkaitan dengan pengaturan suhu tubuh manusia yang berpusat pada hypothalamus. Thermoregulasi merupakan pengetahuan biologi dan fisika, sehingga konsep thermoregulasi bisa di integrasikan ke dalam materi pelajaran IPA. Materi yang dipandang sesuai dengan kajian thermoregulasi ini adalah materi suhu dan kalor.
Materi suhu dan kalor yang menjadi topik pembelajaran di sekolah merupakan bagian penting dalam pembelajaran yang dapat diintegrasikan dengan thermoregulasi. Konsep suhu dan kalor mempunyai karakteristik tertentu yang dapat digunakan untuk menganalisis fenomena thermoregulasi [7,8]. Substansi karakteristik materi suhu dan kalor menggambarkan proses dari fenomena pengaturan suhu tubuh manusia (thermoregulasi). Keterkaitan karakteristik tersebut menjadi dasar pertimbangan pengintegrasian fenomena thermoregulasi ke dalam materi suhu dan kalor pada pembelajaran IPA di sekolah.

Selanjutnya peserta diberi pelatihan dalam mengembangkan buku guru IPA terpadu. Ada sejumlah konsep yang saling bertautan dalam suatu KD. Agar pembelajarannya menghasilkan kompetensi yang utuh, maka konsep-konsep tersebut harus dipertautkan (connected) dalam pembelajarannya. Pada model connected ini konsep pokok menjadi materi pembelajaran inti, sedangkan contoh atau terapan konsep yang dikaitkan berfungsi untuk memperkaya materi.

\section{Hasil dan Diskusi}

Sebelum memulai pelatihan kepada guru-guru MGMP IPA di Pasaman Barat, terlebih dahulu guru-guru diminta mengisi angket tentang kompetensi guru yang telah dimiliki guru-guru. Hasil angket dapat dilihat pada Gambar 1.

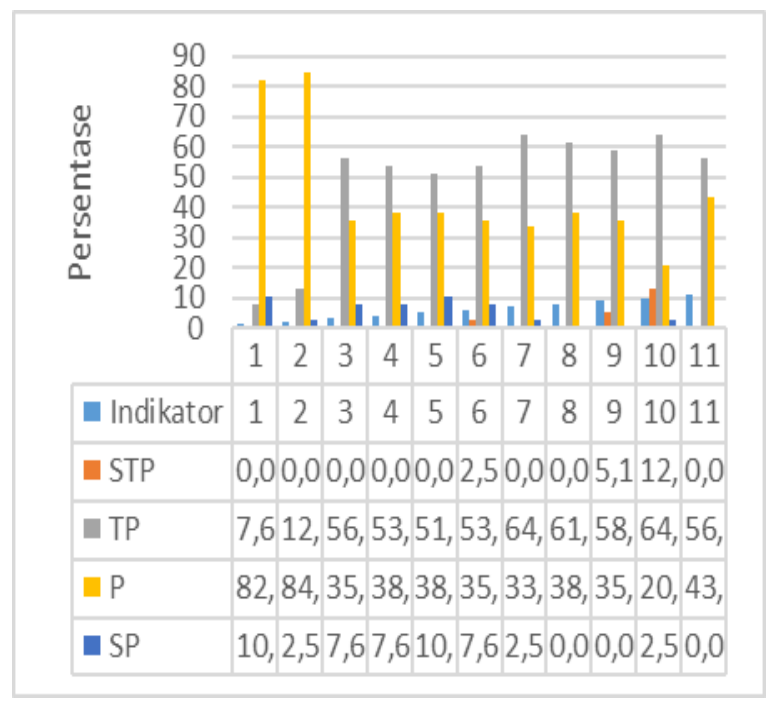

Gambar 1. Hasil angket kompetensi guru-guru IPA 
Keterangan: (1). Saya memahami maksud dari pembelajaran terpadu; (2), Saya mengetahui kelebihan pembelajaran terpadu; (3). Saya mampu menerapkan langkah-langkah pembelajaran terpadu dalam proses pembelajaran ; (4) Saya memahami tipe-tipe pembelajaran terpadu; (5) Saya megetahui tipetipe pembelajaran terpadu yang sesuai dengan pembelajaran IPA ; (6). Saya mampu memadukan materi Fisika, Biologi, dan Kimia secara terpadu dengan menggunakan tipe pembelajaran terpadu tertentu; (7). Saya mampu merancang aktifitas peserta didik sesuai dengan pembelajaran terpadu; (8). saya memahami syarat yang perlu diperhatikan dalam menentukan tema; (9). Saya mampu menyatukan beberapa Kompetensi Dasar sehingga menjadi sebuah tema; (10). Saya mampu merancang buku guru dan buku siswa pembelajaran terpadu; (11). Saya mampu menerapkan pendekatan saintifik dalam setiap fase pembelajaran terpadu.

Dari Gambar 1 terlihat bahwa hampir semua guru yang memahami maksud dari pembelajaran terpadu dan kelebihan pembelajaran terpadu. Namun lebih dari separuh guru yang kesulitan menerapkan langkah-langkah pembelajaran terpadu dalam proses pembelajaran, kurang memahami tipe-tipe pembelajaran terpadu, kurang mampu memadukan materi Fisika, Biologi, dan Kimia secara terpadu dengan menggunakan tipe pembelajaran terpadu tertentu, kurang mampu merancang aktifitas peserta didik sesuai dengan pembelajaran terpadu, kurang memahami syarat yang perlu diperhatikan dalam menentukan tema, kurang mampu menyatukan beberapa Kompetensi Dasar sehingga menjadi sebuah tema, mampu merancang buku guru dan buku siswa pembelajaran terpadu, dan kurang mampu menerapkan pendekatan saintifik dalam setiap fase pembelajaran terpadu.

Dari hasil wawancara dan isian komentar dan saran dari guru-guru diketahui sebagai berikut ini: Pada dasarnya guru-guru sudah mencoba melaksanakan kurikulum IPA Terpadu di SMP, mengkaitkan materi Fisika, Biologi, Kimia dan IPBA dalam pembelajaran, namun hasilnya masih jauh dari apa yang diharapkan. Disamping itu penggunaan buku guru sebagai panduan guru dalam pembelajaran masih sangat sulit untuk dimengerti oleh guru sehingga apa yang kita harapkan tidak tercapai.

Buku guru masih menggunakan bahasa dan kalimat yang rancu dan susah dipahami tujuan apayang dimaksud dalam pembelajaran. Guru Masih sulit melakukan langkah-langkah menyusun perencanaan terutama menentukan KD dan indikator. Guru-guru masih merasa kesulitan dalam menerapkan pembelajaran terpadu. Harapan guru guru Setelah kegitan ini, mudahmudahan guru IPA bisa lebih mengembangkan buku guru IPA yang sesuai dengan tuntutan kurikulum. Kemudian ada guru yang berpendapat penerapan KI3 memang sangat cocok untuk dilaksanakan di sekolah di Indonesia. Tetapi untuk daerah tertentu mungkin tidak cocok karena latar belakang imtag siswa begitu juga dasar pendidikan orang tua.

Lebih lanjut dari isian angket, menurut guru kelemahan dari IPA terpadu karena kebanyakan guru IPA sekarang berasal dari ilmu yang berbeda seperti, Biologi, Fisika dan Kimia. Guru-guru pernah mengikuti pelatihan tentang pembelajaran terpadu, tetapi bagi guru merasa sulit untuk mengimplementasikannya data data PBM. Selain kurang memahami teknik, juga buku panduan yang belum terpadu

Saran dari guru untuk kegiatan pelatihan ini adalah: diharapkan setelah mendapatkan penjelasan dari narasumber, guru dapat memiliki pengetahuan yang tepat untuk pengajaran IPA Terpadu. Harus dilakukan semacam lokakarya samapai dihasilkan produk-produk. Agar kalimat dan bahasa yang dipakai dalam buku guru lebih fokus kepada apa yang diharapkan tercapai dan dipahami.

Selain itu guru berharap supaya bisa lebih memahami pembelajaran yang terpadu Semoga ada pelatihan tentang pembelajaran terpadu ini bagi guru-guru IPA terutama bagi kami guruguru yang masih tertinggal. Agar siswa tidak dituntut dengan ujian-ujian yang sudah dibatasi materinya sehingga guru leluasa berkreatifitas untuk melakuakan pembelajaran.

Guru meminta penjelasan terperinci terkait hal diatas dengan contoh konkrit dalam pembelajaran dan kondisi sekolah sehari-hari. Oleh karena itu pada kesempatan tersebut guru-guru membutuhkan pencerahan mengenai cara yang 
paling sfektif dalam penerapan pembelajaran terpadu tersebut

Setelah kegiatan ini, guru-guru berharap bisa lebih mengembangkan buku guru IPA yang sesuai dengan tuntutan kurikulum Guru IPA terpadu harus mampu memadukan antara Fisika, Kimia, Biologi. Guru harus mampu menyampaikan kepada peserta didik, sehingga peserta didik paham tentang materi yang disampaikan. Guru perlu lebih lanjut mempelajari dan mengetahui lebih dalam tentang IPA terpadu sesuai KI3 pada abad 21. Guru meminta diberi bimbingan dalam memadukan materi Fisika, Biologi dan Kimia. Guru diberi bimbingan untuk merancang aktifitas yang sesuai dengan pebelajaran terpadu. Guru diberi bimbingan dalam menyatukan kompetensi dasar menjadi sebuah tema. Pemberian bimbingan pada pembelajaran terpadu untuk guru IPA. Untuk meningkatkan kompetensi guru diharapkan agar diadakan pelatihan-pelatihan. Memberikan panduan yang terarah sesuai dengan peningkatan materi yang diajrkan. Semoga dengan kegiatan ini, guru-guru dapat membuat buku guru, sehingga

Setelah tim pengabdian memperoleh data awal tentang kompetensi guru dan saran-saran dari guru untuk pelaksanaan kegiatan ini, kemudian tim pengabdian masyarakat melakukan pengarahan dan bimbingan teknis kepada guruguru MGMP IPA di Pasaman Barat. Setelah dilakukan bimbingan teknis kemudian diberikan angket dengan indikator yang sama kembali untuk melihat perubahan kompetensi dari guruguru IPA. Hasilnya dapat dilihat pada Gambar 2.

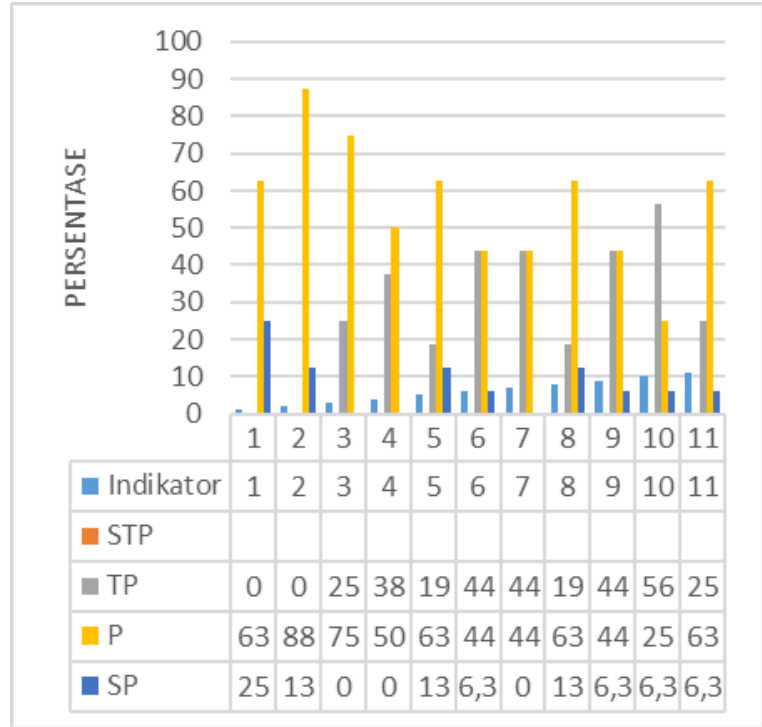

Gambar 2. Hasil perubahan kompetensi guru setelah bimtek

Dari Gambar 2 terlihat bahwa bimtek penyusunan buku guru IPA Terpadu untuk guruguru di MGMP Pasaman Barat mampu meningkatkan kompetensi guru-guru. Semua guru yang memahami maksud dari pembelajaran terpadu dan kelebihan pembelajaran terpadu. Lebih dari separuh guru mampu menerapkan langkah-langkah pembelajaran terpadu dalam proses pembelajaran, guru mampu memahami tipe-tipe pembelajaran terpadu, mampu memadukan materi Fisika, Biologi, dan Kimia secara terpadu dengan menggunakan tipe pembelajaran terpadu tertentu, mampu merancang aktifitas peserta didik sesuai dengan pembelajaran terpadu, memahami syarat yang perlu diperhatikan dalam menentukan tema, mampu menyatukan beberapa Kompetensi Dasar sehingga menjadi sebuah tema, mampu merancang buku guru dan buku siswa pembelajaran terpadu, dan mampu menerapkan pendekatan saintifik dalam setiap fase pembelajaran terpadu.

Adapun tanggapan dari guru-guru setelah bimtek adalah guru menjadi lebih tahu tentang pembelajaran terpadu. Guru-guru agar pelatihan ini untuk dilanjutkan lagi, sehingga betul-betul dapat dilaksanakan. Dari analisis Kompetensi Dasar (KD), guru berpendapat tidak semuanya dapat diintegrasikan. Guru masih perlu 
bimbingan lebih lanjut pada pembelajaran IPA terpadu.

Selanjutnya untuk mengetahui kesiapan bimteks sudah berjalan sebagaimana yang diharapkan, maka tim pengabdian menyebarkan angket ke pada guru-guru. Hasil angketnya dapat dilihat pada Gambar 3.

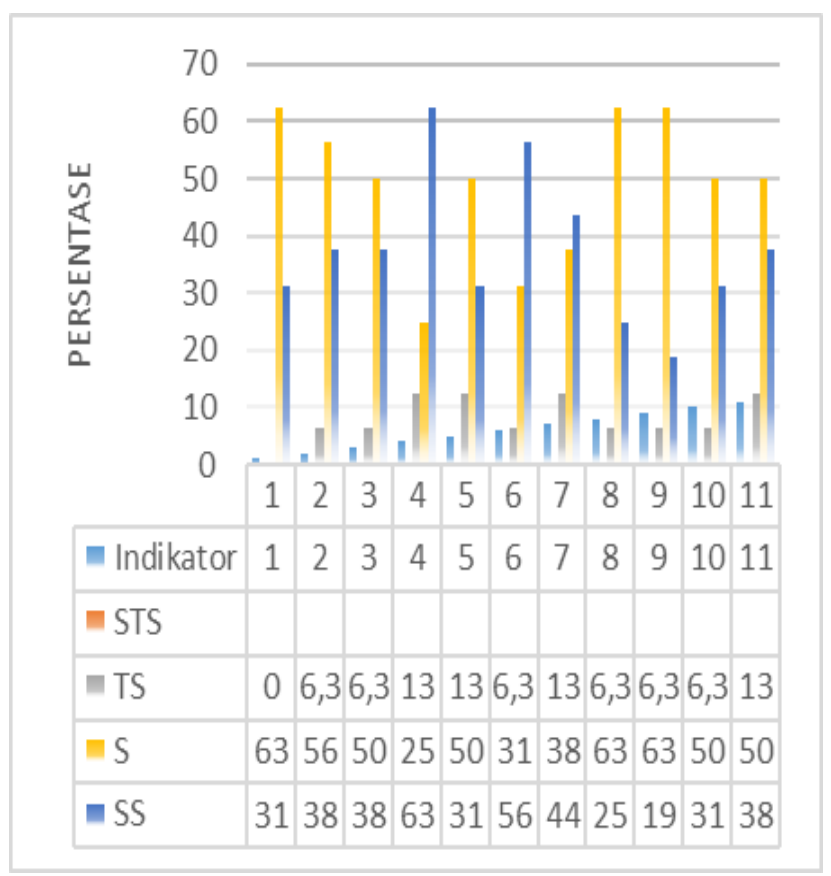

Gambar 3. Hasil angket kesiapan Bimtek

\section{Keterangan}

$\begin{array}{cl}1 & \text { Kesiapan Administrasi } \\ 2 & \text { Kesiapan Humas dan Dokumentasi } \\ 3 & \text { Kesiapan Transportasi } \\ 4 & \text { Kesiapan Tempat } \\ 5 & \text { Kesiapan Materi } \\ 6 & \text { Kesiapan Kosumsi / Akomodasi } \\ 7 & \text { Kesiapan Acara Pembukaan } \\ 8 & \text { Pelaksanaan Penyajian } \\ 9 & \text { Pelaksanaan Diskusi } \\ 10 & \text { Kegiatan Sosialisasi } \\ 11 & \text { Pelaksanaan Penutupan }\end{array}$

Dari Gambar 3 dapat disimpulkan bahwa untuk semua indikator kesiapan bimteks, guru-guru peserta bimtek menilai bahwa persiapan bimteks, mulai dari pembukaan, materi, kosumsi, evaluasi dan lain-lain sudah berjalan dengan baik.

Selanjutnya untuk mengetahui bahwa bimtek berjalan secara efektif, disebar angket dan hasilnya dapat dilihat pada Gambar 4.

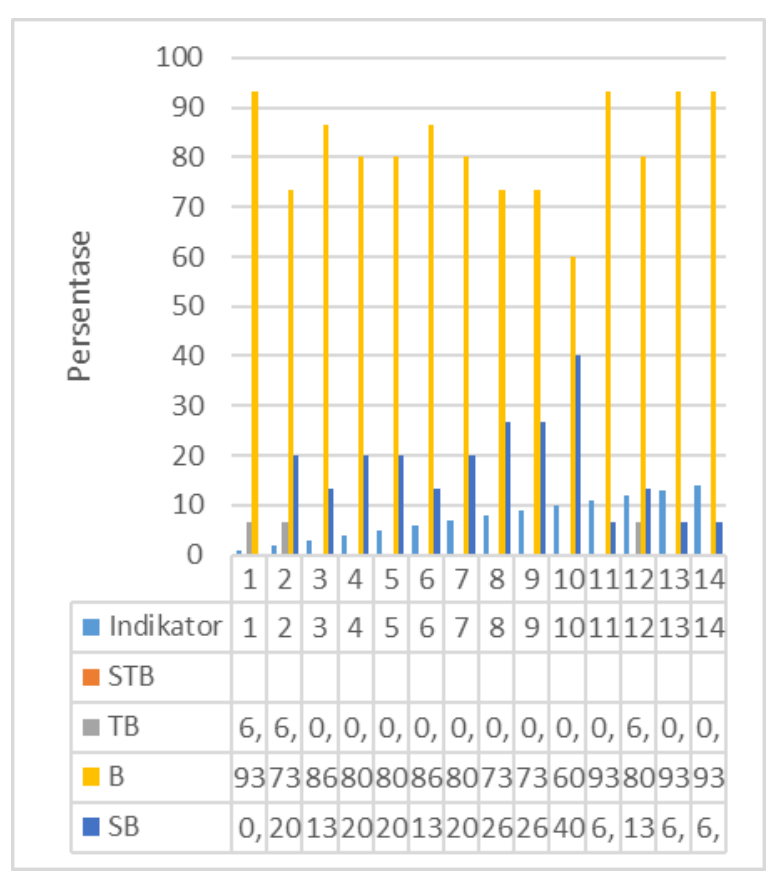

Gambar 4. Hasil angket efektivitas angket

Keterangan

1 Ketepatan waktu penyajian

2 Kesiapan Bahan Ajar

3 Penguasaan materi Pelatihan

4 Sistematika penyajian materi

5 Metode Penyampaian Materi

6 Kemampuan mentransfer materi pelatihan

7 Penguasaan kelas dan komunikasi dengan peserta

8 Kemampuan memotivasi peserta pelatihan

9 Kemampuan menjawab pertanyaan peserta pelatihan

10 Perhatian terhadap pendapat dan pertanyaan peserta

11 Efektifitas penggunaaan waktu pelatihan

12 Kemampuan instruktur secara keseluruhan

13 Tingkat penyerapan/penguasaan materi pelatihan oleh peserta

14 Alokasi waktu yang disediakam

Dari Gambar 4, terlihat bahwa hampir semua guru menilai bimtek berjalan secara efektif baik dalam penyampaian materi maupun latihan penyusunan buku guru IPA terpadu dengan pendekatan scientifik. 


\section{Kesimpulan}

Dari hasil Bimtek penyusunan buku guru IPA Terpadu dengan pendekatan scientifik yang dilakukan kepada guru-guru di MGMP Kabupaten Pasaman Barat dapat disimpulkan bahwa terjadi peningkatan kompetensi guru tentang pembelajaran IPA terpadu. Dari Aspek kesiapan bimbingan teknis juga berjalan baik. Dari aspek efektifitas bimbingan teknis lebih 70 $\%$ guru menyatakan sudah pada kriteria baik.

\section{Ucapan Terima Kasih}

Ucapan terima kasih kepada Universitas Negeri Padang yang telah memberi sokongan dana PNBP 2019 untuk pelaksanaan kegiatan PKM ini.

\section{Pustaka}

[1] Martin, David J. Elementary Science Methods. A Constructivist Approach, Belmont, California: Wadsworth; 2000.

[2] Amien M. Mengajar Ilmu Pengetahuan Alam (IPA) dengan Metode Discovery dan Inkuiri. Jakarta P2LPTK; 1987.

[3] Depdiknas. Standar Kompetensi Mata Pelajaran IPA. Jakarta: Balitbang Depdiknas; 2006.

[4] Mahmud D. Belajar Pembelajaran. Raja Grafindo Persada Jakarta.; 1994.

[5] Wenning C J. Levels of inquiry: Hierarchies of pedagogical practices and inquiry processes. Journal of Physics Teacher Education Online; 2005; 2(3) : 3-11.

[6] Wenning C J. Levels of inquiry: Using inquiry spectrum learning sequences to teach science. J. Phys. Tchr. Educ. Online ; 2012: 5(4).

[7] Gabriel. Fisika Kedokteran. Jakarta: Penerbit Buku Kedokteran EGC. 1996.

[8]Croner A H. Fisika Untuk Ilmu-Ilmu Hayati. Yogyakarta: Gajah Mada University Press; 1994. 